DOI: $10.31933 /$ DIJEMSS

Received: $13^{\text {th }}$ August 2020, Revised: $20^{\text {th }}$ September 2020, Publish: $18^{\text {st }}$ November 2020

$\begin{array}{|ll|} & \text { DIJEMSS } \\ & \text { DINASTI INTERNATIONAL JOURNAL } \\ & \text { OF EDUCATION MANAGEMENT AND }\end{array}$

\title{
DETERMINANT ANALYSIS OF FINANCIAL RATIO ON STOCK RETURNS IN CONSTRUCTION COMPANIES REGISTERED AT INDONESIA STOCK EXCHANGE 2015-2019
}

\author{
Muhammad Reza Alfianto Siregar ${ }^{1)}$, Pardomuan Sihombing ${ }^{2)}$ \\ ${ }^{1)}$ Magister Manajemen, Universitas Mercubuana, Jakarta, Indonesia, Reezasiregar@gmail.com \\ ${ }^{2)}$ Magister Manajemen, Universitas Mercubuana, Jakarta, Indonesia, \\ pardomuan.sihombing@mercubuana.ac.id
}

Corresponding Author: Muhammad Reza Alfianto Siregar

\begin{abstract}
The growth of the construction sector in Indonesia has indirectly contributed to the growth in the performance of construction companies. This construction performance growth has an impact on stock price movements, apart from the influence of demand and supply of shares. The condition of fluctuating stock price movements requires investors to analyze financial statements before making investment decisions. To find out how the stock price performance can be done by measuring stock returns. In connection with these conditions, the purpose of this study is to analyze the effect of ROE, DER, CR, PBV and TATO on stock returns in construction companies listed on the IDX in 2015 - 2019. This research is included in the category of comparative causal research. The number of samples used in this study were 13 sample companies, with the sampling technique using purposive sampling. The type of data in this study is secondary data taken by the documentation method at Yahoo Finance. The data analysis method uses panel data regression analysis assisted by the Eviews 9.0 software. The results of the study partially show that ROE; DER, CR, PBV, and TATO have a positive and significant effect on stock returns. In addition, ROE, DER, CR, PBV, and TATO simultaneously have a significant effect on stock returns.
\end{abstract}

Keywords: Financial Ratio, DER, CR, PBV, ROE, TATO, Stock Returns, Construction Company

\section{INTRODUCTION}

Based on the Presidential Regulation on National Strategic Projects and the Presidential Regulation on the Development and Development of Domestic Oil Refineries in 8 Economic Policy Packages issued by the end of 2015, it has had an impact on many national developments (kppip.go.id, 2018). However, until the end of November 2017 the completion of the PSN (National Strategic Project) had not yet reached 50\%, the Coordinating Ministry for Economic 
Affairs noted that only four of the 254 projects on the PSN list had been completed. With these conditions the government accelerates development, according to President Rules No. 3 year 2016 regarding the Acceleration of National Strategic Project Implementation and Instruction President No. 6 year 2016 regarding the Acceleration of National Strategic Projects (kppip.go.id, 2018). This condition is indirectly considered to be beneficial to the issuer as shown by the increase in company revenue and the contribution of the construction sector to economic growth, as shown in Figure 1..

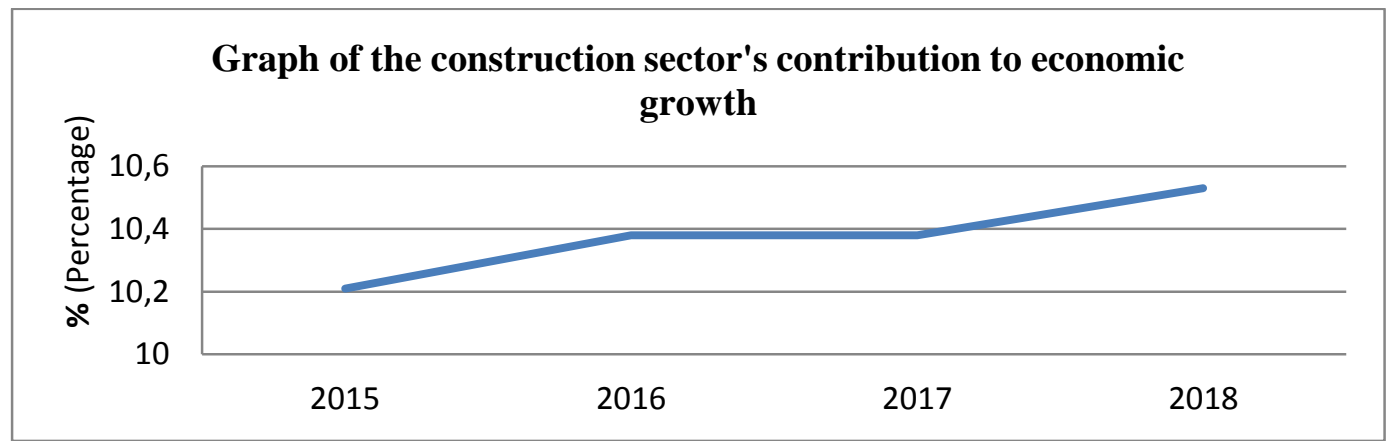

Figure 1. Graph of the construction sector's contribution to economic growth Source: Badan Pusat Statistik, 2019

During 2015 to 2018, the construction sector was recorded as one of the sectors that had a positive impact on economic growth. Based on data from the Central Statistics Agency, Indonesia's economic growth in 2015 was $10.21 \%$, which then increased by $0.9 \%$ to $10.38 \%$ in 2016 (Central Bureau of Statistics, 2019). Although in 2017 the contribution of the construction sector remained at $10.38 \%$, in 2018 there was an increase of $0.15 \%$ to $10.53 \%$ (Central Statistics Agency, 2019). The percentage of this contribution continues to increase until the first quarter of 2019 to 10.75\% (Central Statistics Agency, 2019), where this figure has increased quite significantly compared to the position four years ago which was still in the range of 9\% (Central Statistics Agency, 2019).

An increase in company revenue will affect the increase in company performance as seen through stock price movements. The share price shows the achievements of the company or issuer. Stock price movements are directly proportional to company performance movements (Novasari, 2013), where company performance reflects firm value. Thus, the high company value will affect the increase in stock prices, and vice versa.

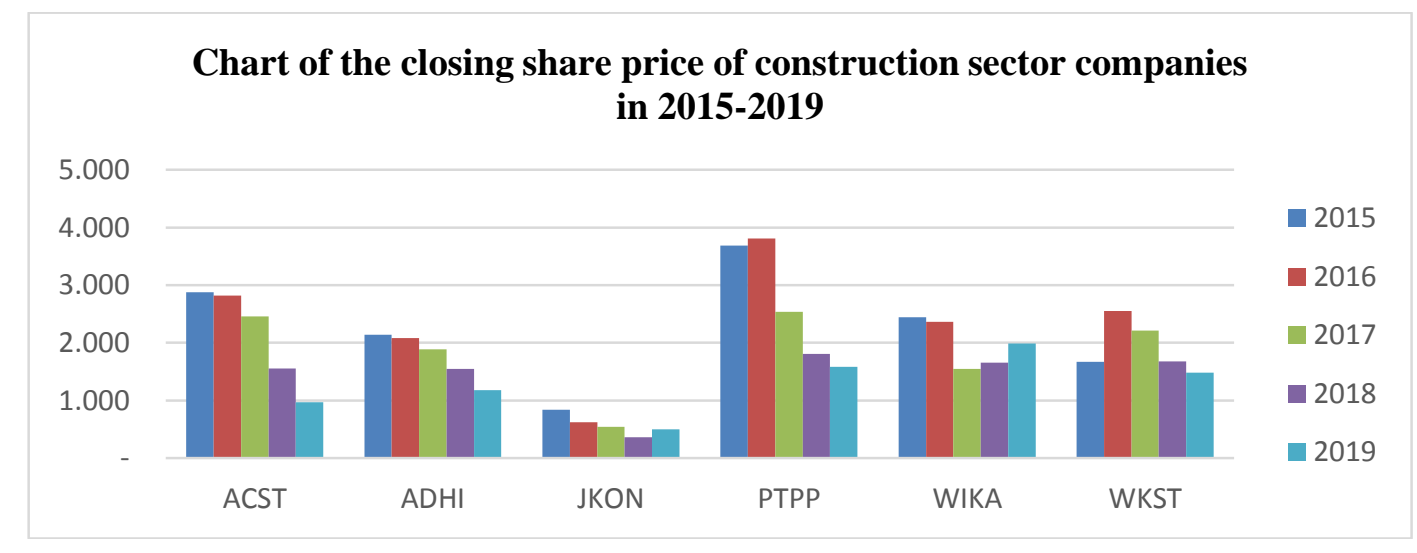


Figure 2. Chart of the closing share price of construction sector companies in 2015-2019 Source : (Yahoo Finance, 2019; BEI, 2019)

Figure 2 shows that stock price movements are volatile, influenced by internal and external factors. Internal factors come from the company, such as projections of company performance, corporate actions and so on, while external factors come from outside the company, such as economic stability, market manipulation, government policies, market supply and demand. (Financial Fervices Authority, 2017; Verawati and Pratiwi, 2016). Due to the fluctuating stock price conditions, analysis of financial statements is needed to ensure the safety of funds invested by investors. To measure the stock performance of construction sector companies, this research uses a stock return proxy to measure stock performance, because the stock price when the analysis is carried out will cause research bias. One of the financial statement analysis techniques that can be used is financial ratios. There are 5 types of financial ratios, but in this study only 5 types of financial ratios are used, including Current Ratio, Debt to Equit Ratio, Return to Equity Ratio, Price Book Value, and Total Asset Turn Over.

Based on the background that has been described, this shows that there is inconsistency in the results of previous studies. Therefore, the purpose of this study is to analyze the effect of financial ratios as proxied by ROE, DER, CR, PBV, and TATO on stock returns. This study contributes to enriching the research literature, as well as providing information about the factors that influence stock prices so that it can be a reference for determining investor policies to buy stocks. This study was analyzed using the panel data regression analysis method on 13 samples of construction companies listed on the IDX in 2015 - 2019. The articles in this study are organized into several sections including part 1 Introduction; section 2 Literature review; section 3 Research methods and analysis of research concepts; section 4 Research results; section 5 Research discussion; section 6 Conclusions and further research.

\section{LITERATURE REVIEW}

In order to developing research hypotheses and concepts, some literature reviews are needed related to the research concept. The current ratio is a measuring tool in the liquidity ratio used to determine how the company's ability to meet its short-term obligations (Subramanyam and John, 2010). Current ratio is calculated by dividing current assets by current liabilities. The greater the ratio of current assets to current liabilities, the greater the company's ability to meet the company's operational needs, especially working capital, which is very important for maintaining financial performance (Imelda, et al, 2018). This shows that the better the current ratio value, the more liquid the company is, thus giving a positive signal to investors to buy shares. This situation will indirectly affect the increase in share prices. According to research by Imelda et al (2018), the current ratio has a positive and significant effect on stock prices in property and real estate companies with a significance value of 0.02 $<0.05$. However, other research shows that the current ratio has no positive and significant effect on stock prices (Deitiana, 2013; Trisnawati, 2012). This situation also shows that the size of the current ratio value has no effect on stock prices.

\section{Current ratio has a significant effect on stock returns}

According to Fahlev (2013), solvency measures how much debt is used in company spending. There are several measuring instruments for solvency ratio, one of which is the debt to equity ratio (DER). Dept to equity ratio is calculated by total debt compared to shareholder equity. The DER ratio provides information on the proportion of providers of 
funds between shareholders and creditors (Darsono, 2005: 54). The lower the DER value, indicating that funding through shareholders is getting smaller, so that the risk borne by investors is getting smaller and can increase the share price (Trisnawati, 2012). This situation is in line with research conducted by Novasari (2013) which shows that DER affects stock prices in textile companies listed on the IDX in 2009-2011. Other research shows that DER has a negative and insignificant effect on stock prices (Amandan, 2012; Trisnawati, 2013; Patriawan, 2011).

\section{Dept to equity ratio (DER) significantly influence stock returns}

Return on Equity is one of the profitability ratios that measures the company's ability to get a return on shareholder investment (Imelda, et al, 2018). The higher the ROE value, the more efficient the company uses its own capital to generate profits (Brigham, 2001). This situation will give a positive signal to investors to buy shares, because the company will get promising profits in the future, so that this situation will encourage share prices to rise. Thus, Return on equity (ROE) has a significant positive effect on stock prices (Nugraha and Sudaryanto, 2016). In the research of Trisnawati (2013) and Patriawan (2011), the results show that ROE has a negative and insignificant effect on stock prices.

\section{Return on equity (ROE) significantly influence stock returns}

The market value ratio is also known as the stock ratio. One of the tools to measure the market value ratio is the price book value (EPS). Price book value (PBV) is a ratio used to measure stocks in undervalued or overvalued conditions (Suselo, et al, 2015), which is calculated by comparing the stock price to the company's book value. Companies that have a good PBV value, with a PBV value greater than one indicate that the company's performance is very good (Asmi, 2014). Thus, the higher the PBV ratio of a company, the higher the company's performance, which in turn has an impact on the company's stock price. This question is in line with several previous studies which show that price book value (PBV) has a positive and significant effect on stock prices (Suselo, et al, 2015; Sha, 2015; Asmi, 2014; Dewi and Suaryana, 2013).

\section{Price Book Value (PBV) significantly influence stock returns}

According to Putra, et al. (2013) Total assets turnover ratio is a measure of the extent to which these assets have been used in company activities or show how many times the Operating Assets rotates in a certain period. Total assets turnover ratio is one of the proxies of the activity ratio used to measure the efficiency level of the company's asset management. Efficient asset management will have an impact on increasing company profits, which then become a sign for investors (Z., 2017). With this signal, it will attract investors to buy shares of the company. There are several studies which state that total assets turnover has a significant.

\section{Total Assets Turnover (TOTA) significantly influence stock returns}

\section{RESEARCH METHODS}

Based on the research objectives, namely to determine the effect of ROE, DER, CR, TATO and PBV on stock returns, the type of research used is causal comparative research (Causal Comparative Research). This research was conducted to compare the similarities and differences of two or more facts and the properties of the object under study based on a certain frame of mind, as shown in Figure 3.In this study, the variables were still independent but for samples of more than one or more samples. different times. 


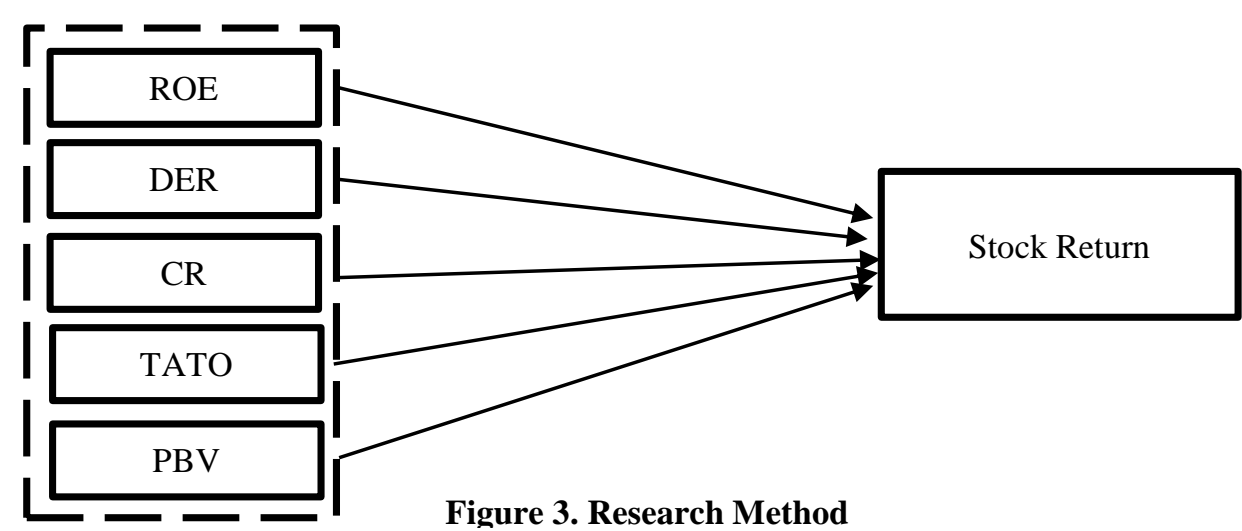

The data in this study is secondary data which refers to the research population of 19 construction companies listed on the Indonesia Stock Exchange for the period 2015-2019. Sampling was done by using purposive sampling method. According to Sugiyono (2010), purposive sampling is a technique for determining research samples with certain considerations that aim to make the data obtained more representative. There are several criteria determined by sampling, including (1) construction companies listed on the Indonesia Stock Exchange for the period 2015-2019; (2) construction companies that have IPO after 2015. Based on these criteria, the final sample of research is 13 construction companies, including Acset Indonusa Tbk (ACST), Adhi Karya (Persero) Tbk (ADHI), Bukit Darmo Property Tbk (BKDP). , Duta Graha Indah Tbk (DGIK), Indonesia Pondasi raya Tbk (IDPR), Jaya Konstruksi Manggala Pratama Tbk (JPON), Hanson International Tbk (MYRX), Nusa Raya Cipta Tbk (NRCA), Housing Development (Persero) Tbk (PTPP), Surya Semesta Internusa Tbk (SSIA), Total Bangun Persada Tbk (TOTL), Wijaya Karya (Persero) Tbk (WIKA), and Waskita Karya (Persero) Tbk (WSKT).

The data collection technique used in this research is documentation data. Documentation data are the company's financial reports that are downloaded from the Indonesia Stock Exchange and the company's website. In addition, data collection was also carried out through books, journals and papers related to this research, with the aim of obtaining a theoretical basis and analytical techniques in solving problems. The data analysis method used in this research is panel data regression analysis. According to Basuki (2017) panel data regression is a regression technique that combines time series data with crosssection data. Several stages were carried out before the panel data analysis was carried out, including descriptive analysis, stationary test or outlier test, determining the panel data regression model, classical assumption test, and hypothesis testing assisted by Eviews 9.0 software.

\section{FINDINGS AND DISCUSSION}

\section{a. Variable Descriptive Analysis}

Descriptive data in table 1 provides an overview of the research variables, so the researcher will describe in detail the data used as variables grouped in descriptive statistics. The ROE value ranges from $-3,951$ to 0.277 , with the highest value from Surya Semesta Internusa in 2017 and the lowest value from Acset Indonusa in 2019. The standard deviation value of the ROE variable is 0.532 . The DER value ranges from 0.232 to 35.466 , with the highest value from Acset Indonusa in 2019 and the lowest value from Hanson International in 2016 and a standard deviation value for DER of 4.501. The CR value ranges from 0.208 to 2.368, with the highest value from Surya Semesta Internusa in 2019 and the lowest value from Bukit Darmo Property in 2016 and the standard deviation value of the CR variable is 
0.452. TATO values range from 0.010 to 1.805 , with the highest score from Nusa Raya Cipta in 2015 and the lowest value from Hanson International in 2015 with a standard deviation value of the TATO variable being 0.365. PBV values ranged from 0.112 to 7.047 , with the highest value from Jaya Konstruksi Mandala Pratama in 2015 and the lowest value from Hanson International in 2015 and a standard deviation value of 1.187. The value of Stock Returns ranges from -0.633 to 0.918, with the highest value from Bukit Darmo Property in 2015 and the lowest value from Hanson International in 2015. The standard deviation value of the Stock Return variable is 1.187 .

\begin{tabular}{lllllll}
\hline Deskriptif & ROE & DER & CR & TATO & PBV & Return Saham \\
\hline Mean & 0.002 & 2.234 & 1.305 & 0.576 & 1.406 & -0.107 \\
\hline Median & 0.091 & 1.402 & 1.351 & 0.527 & 0.940 & -0.131 \\
\hline Maximum & 0.277 & 35.466 & 2.368 & 1.805 & 7.047 & 0.918 \\
\hline Minimum & -3.951 & 0.232 & 0.208 & 0.010 & 0.112 & -0.633 \\
\hline Std. Dev. & 0.532 & 4.501 & 0.452 & 0.365 & 1.187 & 0.266 \\
\hline \multicolumn{7}{c}{60} \\
\hline Observations & 60 & 60 & 60 & 60 \\
\hline \multicolumn{7}{c}{ Sumber: Hasil analisa penulis (2020) }
\end{tabular}

\section{b. Panel Regression Model Determination}

To select the appropriate regression model used in this study. There are three alternative methods used for testing the regression model to obtain a good model, namely methods with common effect models, fixed effect models and random effect models. After calculating the three alternative models, then selecting among the three alternative models is carried out to obtain the right model through the Chow test, Hausman test, Langrange Multiplier model test. The results of selecting the panel data regression model using the common effect model are shown in Table 2.

Table 2 Conclusion Selection of Panel Data Regression Model

\begin{tabular}{|c|c|c|c|c|c|c|}
\hline $\begin{array}{l}\text { Dependent } \\
\text { Variable }\end{array}$ & $\begin{array}{l}\text { Independent } \\
\text { Variable }\end{array}$ & $\begin{array}{l}\text { Chow Model } \\
\text { test }\end{array}$ & $\begin{array}{l}\text { Hausman } \\
\text { Test }\end{array}$ & Model & LM Model Test & Conclusion \\
\hline $\begin{array}{l}\text { Stock } \\
\text { Return }\end{array}$ & $\begin{array}{l}\text { ROE, DER, } \\
\text { CR, TATO, } \\
\text { PBV }\end{array}$ & $\begin{array}{l}\text { Prob. }>\alpha, \text { H0 } \\
\text { accepted use } \\
\text { Common } \\
\text { Effect Model }\end{array}$ & $\begin{array}{l}\text { Prob. > } \\
\text { accepted } \\
\text { Random } \\
\text { Model }\end{array}$ & $\begin{array}{r}\alpha, \quad \mathrm{H} 1 \\
\text { use } \\
\text { Effect }\end{array}$ & $\begin{array}{l}\text { Prob. }>\alpha, \mathrm{H} 0 \\
\text { accepted use } \\
\text { Common } \\
\text { Effect Model }\end{array}$ & $\begin{array}{l}\text { accepted use } \\
\text { Common Effect } \\
\text { Model }\end{array}$ \\
\hline
\end{tabular}

Source: The results of the analysis using Eviews 9.0.

\section{c. Data Regression Analysis Panel}

\section{Simultaneous Test}

Table 3 Results of the F-Test Analysis of the Path Diagram Model

\begin{tabular}{|c|c|c|c|c|}
\hline Diagram Model & Dependent Variable & $\begin{array}{l}\text { Independent } \\
\text { Variable }\end{array}$ & $\begin{array}{l}\text { F-Statistics } \\
\text { Value }\end{array}$ & Prob. \\
\hline $\begin{array}{l}\text { Structure } \\
\text { Model }\end{array}$ & Stock Return & $\begin{array}{l}\text { ROE, DER, CR, } \\
\text { TATO, PBV }\end{array}$ & 52.7413 & $0.00000 *$ \\
\hline
\end{tabular}

Source: The results of the analysis using Eviews 9.0 
Based on table 3 above, it is known that RETURN (Y) as the dependent variable has a value of $\mathrm{F}=52.7413$, and a value of Prob. $=0.0000$. While the value of $\mathrm{F}$ table with $\mathrm{df}=\mathrm{n}-\mathrm{k}-$ $1=54$, and $\mathrm{k}=5$, the value of $\mathrm{F}=2.39$ is obtained, it can be seen that the value of $\mathrm{F}$ Statistic $=52.74>\mathrm{F}$ table value $=2.39$. Therefore $\mathbf{H}_{0}$ Reject, this means that the independent variables together have a significant effect on the dependent variable.

\section{d. Determination Coefficient Test ( $\mathbf{R}^{2}$ )}

Table 4 Results of the Model Determination Coefficient

\begin{tabular}{llllll}
\hline Model Diagram & $\begin{array}{l}\text { Dependent } \\
\text { Variable }\end{array}$ & $\begin{array}{l}\text { Independent } \\
\text { Variable }\end{array}$ & R-Square & Adjusted R-Squared \\
\hline $\begin{array}{l}\text { Structure Diagram } \\
\text { Model }\end{array}$ & Stock Return & $\begin{array}{l}\text { ROE, DER, CR, } \\
\text { TATO, PBV }\end{array}$ & 0.8300 & 0.8143 \\
\hline
\end{tabular}

Source: The results of the analysis using Eviews 9.0

Based on table 4 above, it is known that the Adjusted R-Squared value $=0.8143$. This shows that $81.43 \%$ of stock returns are influenced by variables ROE $\left(\mathrm{X}_{1}\right)$, DER $\left(\mathrm{X}_{2}\right), \mathrm{CR}$ $\left(\mathrm{X}_{3}\right)$, TATO $\left(\mathrm{X}_{4}\right)$, PBV $\left(\mathrm{X}_{5}\right)$, while the rest $(100 \%-81,43 \%)$ that is $18,57 \%$, Stock returns are influenced by other factors outside of this study. Meanwhile, the path coefficient for other variables outside the research is equal to $\varepsilon 3=\sqrt{1-R^{2}}=\sqrt{1-0,8300}=\sqrt{0,1700}=0,4122$.

\section{e. Hypothesis test (t test)}

This research hypothesis testing using the $t$ test. The $t$ test was conducted to determine the influence of each independent variable individually on the dependent variable. The results of hypothesis testing are as shown in table 5.

Table 5 Hypothesis Testing Relationships between variables

\begin{tabular}{lllll}
\hline $\begin{array}{l}\text { Relationship Between } \\
\text { Variables }\end{array}$ & Coefficient & T Statistics & Prob. & Conclusion \\
\hline ROE -> Stock Return & 0.3605 & 2.020 & 0.048 & Has a Positive Significant Effect \\
\hline DER -> Stock Return & 0.2801 & 2.074 & 0.043 & Has a Positive Significant Effect \\
\hline CR -> Stock Return & 0.2235 & 2.214 & 0.031 & Has a Positive Significant Effect \\
\hline TATO -> Stock Return & 0.1361 & 2.853 & 0.006 & Has a Positive Significant Effect \\
\hline PBV -> Stock Return & 0.2606 & 2.367 & 0.022 & Has a Positive Significant Effect \\
\hline$* a: 0.05$ & & & &
\end{tabular}

Source: The results of the analysis using Eviews 9.0 
The regression interpretation from the table above shows the panel data regression model equation as follows:

$Y=-0,0892+0,3605 X_{1}+0,2801 X_{2}+0,2235 X_{3}+0,1361 X_{4}+0,2606 X_{5}$

Information:

$\mathrm{Y}=$ Dependent Variable (Stock price)

$\mathrm{X}_{1}=$ Independent Variable 1 (Return on Equity)

$\mathrm{X}_{2}=$ Independent Variable 2 (Debt to Equity Ratio)

$\mathrm{X}_{3}=$ Independent Variable 3 (Current Ratio)

$\mathrm{X}_{4}=$ Independent Variable 4 (Total Asset Turnover)

$\mathrm{X}_{5}=$ Independent Variable 4 (Price to Book Value)

The results of testing the first hypothesis indicate that the relationship between Return on Equity (X1) and Stock Return (Y) is a significant effect with t-count of 2,02 (t-count $>\mathrm{t}$ table $(\mathrm{df}=54)=2,00)$ Prob value. $=0.048<\alpha=0,05$. The coefficient value is positive, which is equal to 0,3605 which shows that the direction of the relationship between Return on Equity $\left(\boldsymbol{X}_{\boldsymbol{1}}\right)$ with Stock Return (Y) is a positive amount 36,05\% the effect. Thus the hypothesis H1 in this study which states that "Return on Equity $\left(\mathrm{X}_{1}\right)$ directly affects the Stock Return (Y)" is accepted.

The results of testing the second hypothesis indicate that the relationship between Debt to Equity Ratio $\left(\mathrm{X}_{2}\right)$ with Stock Return $(\mathrm{Y})$ is significant with t-count of 2,074 (t-count $>\mathrm{t}$ table $(\mathrm{df}=54)=2,00)$ Prob vslue. $=0.043<\alpha=0,05$. he coefficient value is positive, which is equal to 0,2801 which indicates that the direction of the relationship between Debt to Equity Ratio $\left(X_{2}\right)$ with Stock Return (Y) is a positive amount $\mathbf{2 8 , 0 1 \%}$ the effect. Thus the H2 hypothesis in this study which states that "Debt to Equity Ratio $\left(\mathrm{X}_{2}\right)$ directly affects the Stock Return (Y)" is accepted.

The third hypothesis testing shows that the relationship between Current Ratio (X3) and Stock Return $(\mathrm{Y})$ is significant with a t-count of 2,214 ( $\mathrm{t}$-count $>\mathrm{t}$ table $(\mathrm{df}=54)=2.00)$ and the Prob value. $=0.031<\alpha=0.05$. The coefficient value is positive, namely 0.2235 , which indicates that the direction of the relationship between Current Ratio (X3) and Stock Return (Y) is positive at 22.35\%. Thus the hypothesis H3 in this study which states that "Current Ratio (X3) has a direct effect on Stock Returns (Y)" is accepted.

The fourth hypothesis testing shows that the relationship between Total Asset Turnover (X4) and Stock Returns $(\mathrm{Y})$ is significant with a t-count of $2.853(\mathrm{t}$-count $>\mathrm{t}$ table $(\mathrm{df}=54)=2.00)$ and the Prob value. $=0.006<\alpha=0.05$. The coefficient value is positive, namely 0.1361 which indicates that the direction of the relationship between Total Asset Turnover (X4) and Stock Returns (Y) is positive at $13.61 \%$. Thus the hypothesis H4 in this study which states that "Total Asset Turnover (X4) has a direct effect on Stock Returns (Y)" is accepted.

The fifth hypothesis testing shows that the relationship between Price to Book Value (X5) and Stock Return $(\mathrm{Y})$ is significant with a t-count of $2.367(\mathrm{t}$-count $>\mathrm{t}$ table $(\mathrm{df}=54)=2.00)$ and the Prob value. $=0.022<\alpha=0.05$. The coefficient value is positive, namely 0.2606 , which indicates that the direction of the relationship between Price to Book Value (X5) and Stock Return (Y) is positive at $26.06 \%$. Thus the hypothesis H5 in this study which states that "Price to Book Value (X5) has a direct effect on Stock Returns (Y)" is accepted.

\section{Discussion}

\section{a. Effect of ROE on Stock Returns}

The results of hypothesis testing indicate that return on equity has a positive and significant effect on stock returns. The results of this study are in line with the research of Carlo (2014) and 
Hidajat (2018) which explains that roe has a positive and significant effect on stock returns. Previous research also proved that ROE has a positive and significant effect on stock returns, as evidenced by the Sig. (p-value) of $0.004<0.05$ and t-count (2.926)> t-table (1.990) (Andansari et al., 2016). Several previous studies also support the same results that ROE has a positive and significant effect on stock returns (Benyamin \& Endri, 2019; E Endri, 2019). This shows that the higher the $\mathrm{ROE}$ value, the greater the profit the company gets. In the context of this research, stock return is a proxy for stock performance which is manifested through stock prices, thus, the high and low roe values are important information for investors.

The low ROE value is bad news for investors, it will affect investors' interest in buying company shares, because of the low profit generated by the company, and vice versa. In addition, a high ROE value also indicates that the company can manage the company's capital efficiently in generating profits (Brigham, 2001). However, this study contradicts the research of Aisah \& Mandala (2016) and Wijaya (2008) which show that partial ROE testing does not have a positive and significant effect on stock returns. The level of return on equity does not affect investors in making investment decisions, the decline in company returns is not only caused by inefficient capital management, but there are also other factors that can affect the decline in stock returns, such as company external factors (Aisah \& Mandala, 2016). However, ROE is one of the financial ratios used in financial statement analysis to explain the financial health condition of a company before investors make investment decisions, despite the company's external influences such as economic stability, the rupiah exchange rate, and several other economic factors. Thus, good capital management is very important for companies as a form of company effort to maximize profits.

\section{b. Effect of DER on Stock Returns}

The results of hypothesis testing indicate that the dept to equity ratio has a positive and significant effect on stock returns. The results of this study are in line with several previous studies which explain that DER has a positive and significant effect on stock returns (Basalama et al., 2017; Bowens \& Endri, 2018; Sutriani, 2014). However, this study is not in line with previous research which explains that the value of DER does not have a positive effect on stock returns (Benyamin \& Endri, 2019; D. Endri \& Nugraha, 2019; E. Endri, 2018; E Endri, 2019; Endri Endri et al. ., 2019; Erari, 2014; Kesuma \& Gunadi, 2015; Sugiarto, 2012). The high DER ratio explains that the higher the investors bear the risk of the company's liquidity, and this will disrupt the growth of share prices, so that investors are less interested in buying stocks with a higher DER value. However, in the case of certain companies, such as banks or insurance companies, ratio analysis tends to be larger than companies in other sectors, this is because most of the funds they manage are third party funds, where the funds are recorded as debt. In other words, investors must really look at the causes of the high DER value, whether because of the type of company, high current debt or because of long-term debt.

The DER ratio is formed from the ratio of total debt and total equity. Total debt itself is the sum of total current debt and total long-term debt. If the cause of the high DER ratio comes from total current debt which is higher than total long-term debt, then this situation is still acceptable, because current debt is debt that is formed due to the company's operational activities and is shortterm. However, if the value of the DER ratio is formed due to the total amount of long-term debt, then this situation must be watched out for, because high total long-term debt will disrupt the company's growth. In addition, the total long-term debt is high, the company will experience liquidity problems, which if left unchecked, the company will go bankrupt. Not only that, high total short-term debt will suppress company profits due to borrowing costs. Thus, the DER ratio analysis is one of the analyzes that investors need to do. 
The results of hypothesis testing shown in table 5 explain that the current ratio or CR has a positive and significant effect on stock returns. This explains that the ups and downs of the current ratio will have a linear effect on the ups and downs of stock returns. The better the CR value, the better the company's ability to cover the company's current debt through current asset management, and vice versa, the lower the CR value, the more difficult it is for the company to cover the company's current debt. In other words, the higher the value of the CR ratio analysis, the more secure the company's debts to creditors.

The low CR ratio indicates that there are several company accounts such as uncollectible receivables, unsold inventory, or the length of the company's accounts receivable, so that the company has difficulty paying its debts. In addition, a company with a low CR ratio indicates that the company is experiencing liquidity problems (Prihantini, 2009). Therefore, investors prefer companies with high $\mathrm{CR}$ values than low ones. The results of this study are in line with previous research which explains that the current ratio has a positive and significant effect on stock returns (E Endri, 2019; Prihantini, 2009; Sunardi, 2019). However, this study also contradicts previous research which explains that the current ratio has no positive and significant effect on stock returns (Aryanti et al., 2016; E. Endri, 2018; Endri Endri et al., 2019; Nurmasari, 2017; Thrisye \& Simu, 2013).

\section{d. Effect of TATO on Stock Return}

Table 5 explains that Total Asset Turnover (TATO) has a positive and significant effect on stock returns. Total assets turnover ratio is one of the proxies of the activity ratio used to measure the efficiency level of the company's asset management. Total assets turnover ratio is obtained by comparing the sales account to total assets. A high TATO value indicates that company management can manage all its assets to generate revenue for the company and this in turn is considered to increase company profits (Thrisye \& Simu, 2013). Efficient asset management will have an impact on increasing company profits, which then become a sign for investors (Z., 2017), to invest and then have a positive impact on stock prices and stock returns. The results of this study are in line with several previous studies which explain that TATO has a positive and significant effect on stock returns (Mayfi \& Rudianto, 2014; Nuryana, 2013). However, this study also has results with previous research which explains that TATO has no positive and significant effect (Asmi, 2014; Prabawa \& Lukiastuti, 2017; Thrisye \& Simu, 2013).

\section{e. The Effect of PBV on Stock Returns}

The results of hypothesis testing in table 5 show that price to book value (PBV) has a positive and significant effect on stock returns. This study is in line with the research of Dwialesi et al. (2016) who explained that the PBV variable and company size had a significant effect on company stock returns on the Kompas 100 index for the 2012-2014 period. Several previous studies also explained that the PBV ratio has a positive and significant effect on stock returns (Akbar \& Herianingrum, 2015; Purnamaningsih \& Wirawati, 2014). However, this study is also not in line with previous research which explains that the price to book value (PBV) ratio does not have a positive and insignificant effect on stock returns (Anisa, 2015).

Price to book value (PBV) is a ratio used to measure stocks that are undervalued or overvalued (Suselo, et al, 2015), which is calculated by comparing the stock price to the company's book value. Companies that have a good PBV value, with a PBV value greater than one indicate that the company's performance is very good (Asmi, 2014). A high TATO ratio value also indicates that market confidence in the company's future prospects is also high (Anisa, 2015). Not only that, a PBV value that is greater than one indicates that the company has added value (Purnamaningsih \& Wirawati, 2014). In other words, the higher the PBV ratio, the higher the stock price, where the 
higher the company's stock price will have an indirect impact on stock returns. Thus, the analysis of the price book value (PBV) ratio can be used as a factor for investors in making decisions.

\section{CONCLUSION AND RECOMMENDATION}

The purpose of this study was to analyze the effect of financial ratios as proxied by ROE, DER, CR, PBV, and TATO on stock returns. Empirical testing in this study provides several findings. First, the findings in this study indicate that the Return to Equity Ratio (ROE), Dept to Equity Ratio (DER), Current Ratio (CR), Price Book to Value (PBV), Total Asset Turnover (TATO) partially have a positive and significant effect. to stock returns in construction companies listed on the IDX. Second, the results also show that there are financial ratios (ROE, DER, CR, PBV, TATO) simultaneously affecting stock returns. Testing in some of these variables shows that the test results have results consistent with previous research. Third, $81.43 \%$ of Stock Return is influenced by the variables ROE (X1), DER (X2), CR (X3), TATO (X4), PBV (X5), while the rest (100\% - 81.43\%) are $18,57 \%$, Stock Return is influenced by other factors outside of this study.

This study has limitations that can be improved through further research. First, this research is limited to only using the variables ROE, DER, CR, PBV, TATO, so it is necessary to do further research using other internal factors that have the possibility of affecting stock returns. Second, the sample of this study is limited to construction companies, so it is advisable to use a larger sample or to increase the time span of a longer study period to obtain more consistent results than previous studies. For investors before buying shares, it is better if you understand the internal factors of each company to get information and make decisions in investing the existing funds. Information on the ratios in the company's financial statements can reflect the condition of the company.

\section{BIBLIOGRAPHY}

Aisah, A., \& Mandala, K. (2016). Pengaruh Return on Equity, Earning Per Share, Firm Size Dan Operating Cash Flow Terhadap Return Saham. E-Jurnal Manajemen Universitas Udayana, 5(11), 254691.

Akbar, R., \& Herianingrum, S. (2015). PENGARUH PRICE EARNING RATIO (PER), PRICE BOOK VALUE (PBV) DAN DEBT TO EQUITY RATIO (DER) TERHADAP RETURN SAHAM (Studi terhadap Perusahaan Properti dan Real Estate yang Listing di Indeks $\begin{array}{lllll}\text { Saham Syariah } & \text { Indonesia). } & \text { JESTT, } & \text { 2(9), }\end{array}$ https://doi.org/10.1017/CBO9781107415324.004

Amanda, A., dkk. 2012. Pengaruh Debt to Equity Ratio, Return on Equity, Earning Per Share, dan Price Earning Ratio terhadap harga saham (studi pada perusahaan food and beverages yang terdaftar di BEI tahun 2008 - 2011).

Andansari, Raharjo, \& Andini. (2016). Pengaruh Return On Equity (ROE), Price Earning Ratio (PER), Total Asset Turn OVER (TATO) dan Price To Book Value (PBV) Terhadap Return Saham (Studi Kasus Pada Perusahaan Manufaktur Sektor Makanan Dan Minuman Yang Terdaftar Di BEI Periode 2008-2014). Journal Of Accounting, 2(2). https://jurnal.unpand.ac.id/index.php/AKS/article/view/469

Anisa, N. (2015). ANALISIS FAKTOR-FAKTOR YANG MEMPENGARUHI RETURN SAHAM (STUDI KASUS PADA PERUSAHAAN SUB SEKTOR AUTOMOTIVE AND COMPONENTS YANG TERDAFTAR DI BURSA EFEK INDONESIA PERIODE 20102014). Perbanas Review, 1(1), 72-86. https://doi.org/10.1016/j.bbr.2010.05.009

Aryanti, Mawardi, \& Andesta, S. (2016). Pengaruh Roa, Roe, Npm Dan Cr Terhadap Return Saham Pada Perusahaan Yang Terdaftar Di Jakarta Islamic Index (Jii). I-Finance, 2(2), 54-71.

Asmi, T. L. (2014). Current Ratio, Debt To Equity Ratio, Total Asset Turnover, Return on Asset, Price To Book Value Sebagai Faktor Penentu Return Saham. Management Analysis Journal, 3(2) 1-12 https://doi.org/10.15294/maj.v3i2.3953 
Badan Pusat Statistik. 2017. Pendapatan Nasional Indonesia 2012 - 2016. Jakarta: Badan Pusat Statistik. Hal 126.

Badan Pusat Statistik. 2019. [Seri 2010] Distribusi PDB Triwulanan Atas Dasar Harga Berlaku Menurut Lapangan Usaha (Persen), 2014-2019. (http://www.bps.go.id//). Diakses tanggal 27 Oktober 2019.

Badan Pusat Statistik. 2019. Pertumbuhan Ekonomi Indonesia Triwulan II-2019. Berita Resmi Statistik, No. 65/08/Th.XXII, 5 Agustus 2019.

Basalama, I. S., Murni, S., \& Sumarauw, J. S. . (2017). PENGARUH CURRENT RATIO, DER DAN ROA TERHADAP RETURN SAHAM PADA PERUSAHAAN AUTOMOTIF DAN KOMPONEN PERIODE 2013-2015. Jurnal EMBA : Jurnal Riset Ekonomi, Manajemen, Bisnis Dan Akuntansi, 5(2), 1793-1803. https://doi.org/10.18907/jjsre.37.3_343_4

Benyamin, I. A., \& Endri, E. (2019). Determinants of Stock Returns of Building Construction Companies Listed on the Indonesia Stock Exchange Period 2012-2016. Scholars Journal of Economics, Business and Management, 8875, 39-47. https://doi.org/10.21276/sjebm.2019.6.1.6

Bowens, M. J. A., \& Endri, E. (2018). Determinants of Stock Returns of Telecommunications Companies Listed on the Indonesia Stock Exchange. Saudi Journal of Economics and Finance (SJEF), 9414, 194-203.

Brigham, E. F., dan J. F. Weston, "Dasar-Dasar Manajemen Keuangan Jilid 2 Edisi Kesembilan", Penerbit Erlangga, Jakarta, 2001.

Bursa Efek Indonesia. 2019. Daftar Saham. (https://www.idx.co.id/data-pasar/data-saham/daftarsaham/) . Diakses tanggal 27 Oktober 2019.

Carlo, M. (2014). Pengaruh Return on Equity, Dividend Payout Ratio, Dan Price To Earnings Ratio Pada Return Saham. E-Jurnal Akuntansi, 7(1), 150-164.

Darsono dan Ashari, " Pedoman Praktis Memahami Laporan Keuangan", Andi, Yogyakarta, 2005

Deitiana, Tita. 2013. Pengaruh current ratio, return on equity, dan total asset turn over terhadap dividend payout ratio dan implikasi pada harga saham perusahaan LQ 45. Jurnal Bisnis dan Akuntansi, (Online), Vol. 15 (1): 82 - 88. (http://www.tsm.ac.id/JBA). Diakses tanggal 26 September 2019.

Dwialesi, J. B., Putu, N., \& Darmayanti, A. (2016). ISSN : 2302-8912 PENGARUH FAKTORFAKTOR FUNDAMENTAL TERHADAP RETURN SAHAM INDEKS KOMPAS 100 Fakultas Ekonomi dan Bisnis Universitas Udayana ( Unud ), Bali , Indonesia Perekonomian Indonesia kini tengah berkembang pesat. Perkembangan ekonomi Indonesia men. 5(4), 2544-2572.

Endri, D., \& Nugraha, A. (2019). Determinants of Fundamental Stock Return Factors at Mining Company; Analysis Data Panel for Period 2012 - 2017. 7, 79-86.

Endri, E. (2018). Factors Determine Stock Return of Livestock Feed Companies: Common Effect Model Analysis. International Journal of New Technology and Research, 4(5), 263051.

Endri, E. (2019). Determinan Internal Harga Saham Perusahaan Bumn Non Bank yang Terdaftar di Bursa Efek Indonesia. ULTIMA Accounting, 10(2), 124-137. https://doi.org/10.31937/akuntansi.v10i2.976

Endri, Endri, Dermawan, D., Abidin, Z., \& Riyanto, S. (2019). Effect of financial performance on stock return: Evidence from the food and beverages sector. International Journal of Innovation, Creativity and Change, 9(10), 335-350.

Erari, A. (2014). Analisis Pengaruh Current Ratio, Debt To Equity Ratio, dan Return On Asset Terhadap Return Saham Pada Perusahaan Pertambangan di Bursa Efek Indonesia. Jurnal Manajemen Bisnis Universitas Muhammadiyah Yogyakarta, 5(2), 174-191. 
Fahlevi, Ilham Reza. 2013. Pengaruh rasio likuiditas, profitabilitas, dan solvabilitas terhadap harga saham (studi empiris pada industry perbankan yang terdaftar di Bursa Efek Indonesia tahun 2008 - 2010). Skripsi: Universitas Islam Negeri Syarif Hidayatullah Jakarta.

Hidajat, N. C. (2018). Pengaruh return on equity, earnings per share, economic value added, dan market value added terhadap return saham perusahaan sektor pertanian yang terdaftar di bursa efek indonesia periode 2010-2016. Jurnal Ekonomi, 23(1), 62-75. https://doi.org/10.24912/je.v23i1.334

Imelda, dkk. 2018. Pengaruh curent ratio, cash ratio,return on equity dan return on asset terhadap harga saham pada perusahaan property dan real estate di Bursa Efek Indonesia. Jurnal Akuntansi FEB Universitas Palangka Raya, (Online). (https://www.researchgate.net/publication/327672874). Diakses tanggal 29 September 2019.

Kesuma, I. K. W., \& Gunadi, G. G. (2015). Fakultas Ekonomi dan Bisnis Universitas Udayana, Bali , Indonesia Gd Gilang Gunadi , Pengaruh ROA , DER , EPS terhadap Return ... menilai kinerja perusahaan untuk mengestimasi return . Crabb ( 2003 ) dalam mengestimasi harga saham suatu perusahaan . Rasi. E-Jurnal Manajemen Unud, 4(6), 1636-1647.

Kppip.go.id. 2018. Perkembangan pembangunan infrastruktur di Indonesia. (Online), (https://kppip.go.id/tentang-kppip/perkembangan-pembangunan-infrastruktur-diindonesia/). Diakses tanggal 27 September 2019.

Mayfi, F., \& Rudianto, D. (2014). ANALISIS PENGARUH FAKTOR INTERNAL DAN EKSTERNAL PERUSAHAAN TERHADAP RETURN SAHAM. Jurnal MIX: JURNAL ILMIAH MANAJEMEN, 4(3), 348-362. https://doi.org/10.4324/9781315853178

Novasari, Ema. 2013. Pengaruh PER,EPS, ROA dan DER terhadap harga saham perusahaan sub sektor industry textile yang go public di Bursa Efek Indonesia (BEI) tahun 2009 - 2011. Skripsi. Universitas Negeri Semarang.

Nugraha, Rheza D., Sudaryanto, Budi. 2016. Analisis pengaruh DPR, DER, ROE, dan TATO terhadap harga saham (studi kasus pada Perusahaan Industri Dasar dan Kimia yang terdaftar di BEI periode 2010 - 2014). Diponegoro Journal of Management, (Online), Vol: 5 (4) : 1-12. (http://ejournal-s1.undip.ac.id/index.php/management). Diakses 27 September 2019.

Nurmasari, I. (2017). ANALISIS CURRENT RATIO, RETURN ON EQUITY, DEBT TO EQUITY RATIO DAN PERTUMBUHAN PENDAPATAN BERPENGARUH TERHADAP RETURN SAHAM PADA PERUSAHAAN PERTAMBANGAN DI BURSA EFEK INDONESIA 2010-2014. J. Kreatif, 5(1), 112-131.

Nuryana, I. (2013). Pengaruh Rasio Keuangan Terhadap Return Saham Perusahaan LQ 45 di Bursa Efek Jakarta. Jurnal Akuntansi Aktual, 2(2), 57-66. https://ojs.unud.ac.id/index.php/Manajemen/article/view/38414

Otoritas Jasa Keuangan. 2017. Penyebab Naik Turun Harga Saham Suatu Perusahaan. https://www.google.com/url?sa=t\&rct=j\&q=\&esrc=s\&source=web\&cd=5\&cad=rja\&uact= 8\&ved=2ahUKEwi2zKav4bvlAhURg-

YKHe0NARAQFjAEegQIARAB\&url=https\%3A\%2F\%2Fsikapiuangmu.ojk.go.id\%2FFro ntEnd\%2FCMS\%2FArticle\%2F10507\&usg=AOvVaw1cZwWZkRNOIPEuEK4y2Nlo . Diakses tanggal 27 Oktober 2019

Patriawan, Dwiatma. 2011. Analisis Pengaruh Earning Per Share (Eps), Return On Equity (Roe), Dan Debt To Equity Ratio (Der) Terhadap Harga Saham Pada Perusahaan Wholesale And Retail Trade Yang Terdaftar Di Bursa Efek Indonesia (BEJ) Tahun 2006 - 2008.

Prabawa, D. W., \& Lukiastuti, F. (2017). Analisis Pengaruh Kinerja Keuangan, Manajemen Risiko Dan Manajemen Modal Kerja Terhadap Return Saham. Jurnal Manajemen Indonesia, 15(1). 1. https://doi.org/10.25124/imi.v15i1.388 
Prihantini, R. (2009). Analisis Pengaruh Inflasi, Nilai Tukar, ROA, DER DAN CR Terhadap Return Saham. Jurnal Bisnis Strategi, 18(2), Universitas Diponegoro, Semarang. http://eprints.undip.ac.id/18720/1/Ratna_Prihantini.pdf

Purnamaningsih, D., \& Wirawati, N. gusti putu. (2014). Pengaruh return on asset, struktur modal, price to book value dan good corporate governance pada return saham. E-Jurnal Akuntansi Universitas Udayana, 1(9), 1-16.

Sugiarto, A. (2012). Analisa Pengaruh Beta, Size Perusahaan, Der Dan Pbv Ratio Terhadap Return Saham. Jurnal Dinamika Akuntansi, 3(1), 8-14. https://doi.org/10.15294/jda.v3i1.1939

Sihombing, pardomuan. 2018. Coorperate financial management . Bogor : IPB Press

Sunardi, N. (2019). Profitabilitas, Likuiditas, Dan Multiplier Equity Pengaruhnya Terhadap Harga Serta Return Saham Pada Industri Manufaktur Tahun 2012-2017. Inovasi, 6(1), 58. https://doi.org/10.32493/inovasi.v6i1.y2019.p58-73

Sutriani, A. (2014). Pengaruh Profitabilitas, Leverage, Dan Likuiditas Terhadap Return Saham Dengan Nilai Tukar Sebagai Variabel Moderasi Pada Saham Lq-45. Journal of Business and Banking, 4(1), 67. https://doi.org/10.14414/jbb.v4i1.294

Subramanyam, K.R., Wild, John J. 2010. Analisis Laporan Keuangan. Jakarta: PT Salemba Empat

Trisnawati, Mamik. 2012. Analisis pengaruh current ratio (CR), Debt to Equity Ratio (DER), Return on Equity (ROE), Net Profit Margin (NPM), dan Earning Per Share (EPS) terhadap harga saham (studi kasus perusahaan food and beverages yang terdaftar di BEI pada tahun 2009 2012). Diakses 15 Oktober 2019.

Thrisye, R. Y., \& Simu, N. (2013). Return Saham Bumn Sektor Pertambangan Periode 2007-2010. Jurnal Ilmiah Akuntansi Dan Bisnis, 8(2), 75-81.

Upulupui, IG.K.A. 2012. Analisis Pengaruh Rasio Likuiditas, Leverage, Aktivitas, Dan Profitabilitas Terhadap Return Saham (Studi Pada Perusahaan Makanan Dan Minuman Dengan Kategori Industri Barang Konsumsi Di BEJ). Jurnal Jurusan Akuntansi Universitas Udayana. Diakses 15 Oktober 2019.

Verawati, dan Pratiwi, R. 2016. Fluktuasi Harga Saham Perusahaan Manufaktur Yang Terdaftar Di Bei Pasca Tragedi Ledakan Bom Sarinah. Jurnal Ilmiah MBiA, Vol: 15 (1), 1-10.

Wahyu, Dede. 2018. Panduan Investasi Saham. Available from: (https://www.baguz.biz/investasi/saham/apa-itu-pasar-saham-panduan-investasi-saham/)

Diakses 19 Desember 2019.

Wijaya, D. (2008). Pengaruh Rasio Modal Saham Terhadap Return Saham Perusahaan-Perusahaan Telekomunikasi Go Public di Indonesia Periode 2007. Jurnal Manajemen Dan Kewirausahaan, 10(2), 136-152. https://doi.org/10.9744/jmk.10.2.pp.136-152

Yahoo Finance. 2019. Composite-Historical Data. (https://finance.yahoo.com/). Diakses 14 Oktober 